\title{
Физиология
}

DOI: $10.14529 / \mathrm{hsm} 200301$

\section{EFFECTS OF ZIZIPHUS JUJUBE SUPPLEMENTATION ON PRO- AND ANTI-APOPTOTIC PROTEIN EXPRESSION IN NEUTROPHILS AFTER RESISTANCE EXERCISE}

\author{
S.M.Tayebi ${ }^{1}$, tayebism@atu.ac.ir, tayebism@gmail.com, ORCID: 0000-0003-0459-4443, \\ K. Krüger ${ }^{2}$, karsten.krueger@sport.uni-giessen.de, ORCID: 0000-0003-1506-8254, \\ M. Safakar, safakar.m@yahoo.com, ORCID: 0000-0002-6355-2107, \\ P. Bahrami ${ }^{3}$, bahrami.pouran@yahoo.com, ORCID: 0000-0002-0111-2077, \\ G. Tahmasb ${ }^{3}$, tahmasb.g@yahoo.com, ORCID: 0000-0002-6663-4319, \\ A.V. Nenasheva4, nenashevaav@susu.ru, ORCID: 0000-0003-0092-2948 \\ ${ }^{1}$ Allameh Tabataba'i University, Tehran, Iran, \\ ${ }^{2}$ Justus-Liebig-Universität Gießen, Gießen, Germany, \\ ${ }^{3}$ Kerman Branch, Islamic Azad University, Kerman, Iran, \\ ${ }^{4}$ South Ural State University, Chelyabinsk, Russian Federation
}

\begin{abstract}
Introduction. It is suggested that jujube might have beneficial effects on exercise-induced immune perturbations, specifically on neutrophils apoptosis regulation, but its cellular mechanism is unclear. Aim. The aim of this study was to investigate the acute effect of Ziziphus jujuba administration on pro- and anti-apoptotic protein levels in human neutrophils in response to a session of circuit resistance exercise (Ex). Material and Methods. Participants completed an Ex (75\% 1RM, 9 exercises, 3 sets). While one group received a placebo, the other group ( $\mathrm{Zj})$ was supplemented daily with jujube $(0.5 \mathrm{gr} / \mathrm{kg}$ body weight suspended in $2.5 \mathrm{cc}$ distilled water $)$ one hour before Ex. Results. Ex increased the neutrophil level of $\left[\mathrm{Ca}^{2+}\right]_{\mathrm{i}}$, calpain-1 and caspase-3 $(p<0.05)$ while a reduction of calpastatin and XIAP were observed $(p<0.05)$. Zj either suppressed the $\left[\mathrm{Ca}^{2+}\right]_{i}$ or reversed the calpastatin, calpain-1, XIAP, and caspase- 3 responses $(\mathrm{p}<0.01)$. Conclusions. The data indicate that a single session of intensive Ex induced apoptotic signaling in human neutrophils with the involvement of $\left[\mathrm{Ca}^{2+}\right]_{i}$-calpastatin-calpain axis upstream caspase-3. Acute administration of jujube solution before exercise attenuated these effects probably by providing energy sources for neutrophils or by functioning as antioxidants.
\end{abstract}

Keywords: jujube supplementation, resistance exercise, neutrophil apoptosis, $\left[\mathrm{Ca}^{2+}\right]_{i^{-}}$ calpastatin-calpain axis, caspase-3, XIAP.

\section{INTRODUCTION}

Neutrophils are cells which represent a first line defense against pathogens. Besides, they are known to be key regulators of inflammatory responses which die through spontaneous apoptosis at inflamed tissues [16, 17, 31].

A single bout of high intensity exercise is known to mobilize neutrophils from the marginal pool into the circulation [17]. After intensive exercise, several neutrophils function like oxidative burst or migration are temporarily inhibited which is speculated to clinically affect risk of infection. Recently, it was shown that intense exercise affects neutrophils lifespan by modifying their susceptibility to apoptosis [16]. There are conflicting data regarding exercise-induced neutrophil apoptosis. It is demonstrated that acute severe exercise induced an oxidative state in neutrophils which resulted in acceleration of spontaneous neutrophil apoptosis [31]. Besides, it is found that moderate exercise did not affect neutrophil apoptosis, but intensive resistance and endurance exercise delayed neutrophil apoptosis during recovery period [23]. So, what is the explanation to these conflicting results? Maybe focus on cellular and molecular mechanisms.

Previous studies demonstrated that a single session of acute exercise induced DNA fragmentation, mitochondrial membrane depolarization, and increased expression of pro-apoptotic genes (bax and bcl-xS), while expression of antiapoptotic genes (bcl-xL) in rat neutrophils were 


\section{Физиология}

suppressed [15, 18]. Furthermore, exercise was accompanied by an increase of $\mathrm{p} 53$ and caspase- 3 expression, whilep38 MAPK and JNK where phosphorylated [16]. An important anti-apoptotic modulator in neutrophils is represented by calpastatin. A decrease in calpastatin expression may release the constitutively active calpains to cleave Bax into an active fragment and deactivate XIAP [9]. Both calpastatin and calpain-1 represent critical proximal elements in a cascade of proapoptotic events leading to Bax, mitochondria, and caspase- 3 activation, and their altered expression appears to affect life span of neutrophils under pathologic conditions [3]. However, the expression of these calcium-dependent proteins after exercise has not been investigated yet. Recently, exercise induced an increase of intracellular calcium $\left(\left[\mathrm{Ca}^{2+}\right]_{\mathrm{i}}\right)$ transients [23], suggesting the involvement of calpastatin-calpain-calcium axis in neutrophils apoptosis regulation during exercise.

In athletes, an increasing prevalence of supplementation is reported [30]. An important reason for taking supplements is to prevent exercise induced immunodepression and to decrease likelihood of illness [24]. Although supplementation of hydrolyzed whey protein enriched with glutamine dipeptide had no effect on immune cells [7], glutamine supplementation affected exercise induced immune perturbations by reducing neutrophils apoptosis $[15,16,18]$. However, long-term consumption of chemical supplements can be harmful [39]. Accordingly, it is recommended to use natural or herbal supplements $[32,37]$.

Jujube (Ziziphus) is a native plant from southern Europe and Specially Asia [28]. It is known as Chinese date and red date [27]. It also grows in east, southeast and central of Iran, and is called "annab" [12]. Jujube has been traditionally used fresh or processed (dried) as food, food additive and flavoring agent for thousands of years, due to its high nutritional values [19]. Previous studies have revealed that jujube contains various constituents, including triterpenic acids [11] flavonoids [25], cerebrosides [11], amino acids [5], phenolic acids [8], mineral constituents [19], and polysaccharides [13]. Recent studies showed that jujube fruits have multiple bioactivities, such as anticancer [26], hepatoprotective [29], gastrointestinal protective [13], neuroprotective effects [40], antioxidant [4], anti-insomnia, immunostimulating [20], and anti-inflammatory [41]. Accordingly, it is suggested that jujube might have beneficial effects on exercise induced immune perturbations, specifically on neutrophils apoptosis regulation. In this regard, we previously demonstrated that solution supplementation one hour before exercise [34] and one week jujube solution supplementation [35] affected number of Annexin $\mathrm{V}$ positive neutrophils after exercise. However, up to now there are no data about the underlying cellular and molecular mechanisms which might affect balance of pro-and antiapoptotic signals.

\section{MATERIALS AND METHODS}

Participants. The present study was approved by the Research Ethics Committee of the Tarbiat Modares University of Medical Science and was conducted in accordance with the policy statement of the Declaration of Iranian Ministry of Health. Written informed consent was obtained from participants. All subjects were asked to complete a medical examination and fill a medical questionnaire to ensure that during the past month they had not taken any regular medication, smoked, consumed alcohol or taken any regular exercise in the past 2 months, and were free of cardiovascular or metabolic diseases or recent symptoms of upper respiratory tract infection in the month prior to the start of these tests. Volunteers were randomly assigned to 2 groups $(n=7)$ including a Circuit Resistance Exercise (Ex) group with placebo (age: $25 \pm 3$ years, height: $171 \pm 2 \mathrm{~cm}$, weight: $67.5 \pm 4.9 \mathrm{~kg}$ ) and Ex group $(\mathrm{n}=7)$ with Ziziphus jujube $(\mathbf{Z j}) /$ solution (age: $25 \pm 1$ years, height: $180 \pm 4 \mathrm{~cm}$, weight: $74.1 \pm$ $\pm 5.8 \mathrm{~kg}$ ).

One repeat maximum (1-RM) test. 1-RM value was determined by trial in three separate sessions, by adding or removing weights after each attempt, as required. Subjects were allowed to take as much time as they felt necessary to recover from each attempt. This was confirmed by visual and verbal feedback from participants.

Jujube preparation. The semi-dried fruits of $\mathrm{Zj}$ were washed, and seeds were separated and the soft red parts were removed. The samples were dried at $50^{\circ} \mathrm{C}$ and ground to a powder using a mortar [37].

Combination assessment of jujube extraction by gas chromatography-mass spectrometry (GC-MS). Compounds of $\mathrm{Zj}$ extraction were detected by GC-MS by semi-quantitative method. The contents of $\mathrm{Zj}$ extraction compounds were quantified using an internal standard (3-octanol, $99 \%$, Sigma-Aldrich). Wine volatile compounds 
were analyzed using an Agilent 5975 Mass Spectrometer coupled to an Agilent 7890A Gas Chromatograph (Agilent, Santa Clara, USA). A DB-WAX column $(60 \mathrm{~m} \times 0.25 \mathrm{~mm}$ ID and $0.25 \mu \mathrm{m}$ film thickness) was used for separation. The working parameters were as follows: injector temperature of $210^{\circ} \mathrm{C}$, EI source of $230^{\circ} \mathrm{C}$, MS Quad of $150^{\circ} \mathrm{C}$ and transfer line of $210^{\circ} \mathrm{C}$. The initial temperature was $30^{\circ} \mathrm{C}$ for $8 \mathrm{~min}$, which was increased to $150{ }^{\circ} \mathrm{C}$ at a rate of $3{ }^{\circ} \mathrm{C} / \mathrm{min}$. Injector port temperature was $290{ }^{\circ} \mathrm{C}$ and helium used as carrier gas at a flow rate $1.5 \mathrm{ml} / \mathrm{min}$. A total of 15 compounds were positively or tentatively identified by GC-MS that contain $92.27 \%$ the area under the peak totally (Table 1).

Exercise protocol. All participants performed a session of Ex in two cycles, simultaneously. Each cycle contained 9 exercises (seat up, back extension, biceps curl, triceps press, knee extension, knee curl, standing calf raise, chest press, seated row, machines were used in all exercises). The test included three non-stop circuits with a 3-minute active rest period between circuits. Each exercise was performed for $30 \mathrm{~s}$ (about 10-14 repeats) with 1RM of $75 \%$ $[33,36]$.

Supplement protocol and blood collection. The groups had a standard diet program during
3 days before test for unification and nutritional control. They received three meals/day: breakfast $\left(10 \mathrm{kcal} \cdot \mathrm{kg}^{-1} \mathrm{BW}, 70\right.$ carbohydrates, $18 \%$ protein, $12 \%$ fat), lunch (10 kcal $\mathrm{kg}^{-1} \mathrm{BW}, 70 \%$ carbohydrates, $18 \%$ protein, $12 \%$ fat) and, dinner $\left(18 \mathrm{kcal} \cdot \mathrm{kg}^{-1} \mathrm{BW}, 70 \%\right.$ carbohydrates, $15 \%$ protein, $15 \%$ fat). Subjects arrived at the test location, after 12 hours overnight fast, at 08:00 where they rested for about 30 minutes. Then subjects received placebo $\left(2.5^{\mathrm{cc}} / \mathrm{kg}\right.$ of body weight in distilled water sweetened with sugar without calories and colored by food dye) and $\mathrm{Zj}$ solution $\left(0.5 \mathrm{gr} / \mathrm{kg}\right.$ body weight in $2.5^{\mathrm{cc}}$ distilled water) at 08:30 in double-blind manner and rested for about $60 \mathrm{~min}$, at 09:30 all subjects performed the Ex in two cycles, simultaneously. The first peripheral venous blood samples were drawn at 08:30 before supplements of placebo and $\mathrm{Zj}$ solution, second blood samples were taken immediately after exercise at 10:00, then subjects remained seated for $120 \mathrm{~min}$, and the third set of blood samples were taken at 12:00. The research design and blood collection is shown in Fig. 1.

Neutrophil isolation. Neutrophils were purified from venous blood treated with ACD from healthy volunteers by 3-steps: Dextran sedimentation, hypotonic lysis, and Ficoll sedimentation, as described previously [35].

Table 1

Combination assessment of jujube extraction by gas chromatography-mass spectrometry (GC-MS)

\begin{tabular}{|l|c|c|}
\hline \multicolumn{1}{|c|}{ Combination } & The area under the Peak (\%) & Retention time (min) \\
\hline Furfural & 51.33 & 20.21 \\
\hline 4-Pyrone & 9.51 & 17.07 \\
\hline Oleic acid & 6.31 & 39.00 \\
\hline Palmic acid & 4.15 & 35.70 \\
\hline Imidazole & 3.03 & 23.59 \\
\hline Cyclononasiloxane & 2.03 & 42.05 \\
\hline Cyclodecasiloxane & 1.75 & 35.63 \\
\hline Oxantin & 1.61 & 10.65 \\
\hline Guanine & 1.58 & 27.20 \\
\hline Gamma.-Sitosterol & 1.17 & 44.56 \\
\hline Niphimycin & 1.16 & 26.89 \\
\hline Iron & 1.10 & 45.65 \\
\hline Butanediol & 1.07 & 27.00 \\
\hline Phthalic acid & 1.02 & 45.48 \\
\hline Pentasiloxane & 1.01 & 48.34 \\
\hline Dodecanoic acid & 0.97 & 27.616 \\
\hline Octadecamethyl & 0.95 & 32.604 \\
\hline Methyl 2-furoate & 0.92 & 14.28 \\
\hline 1,4-dicarbonic acid & 0.86 & 51.997 \\
\hline Tetradecanoic acid & 0.74 & 31.840 \\
\hline Total & 92.27 & \\
\hline
\end{tabular}




\section{Физиология}

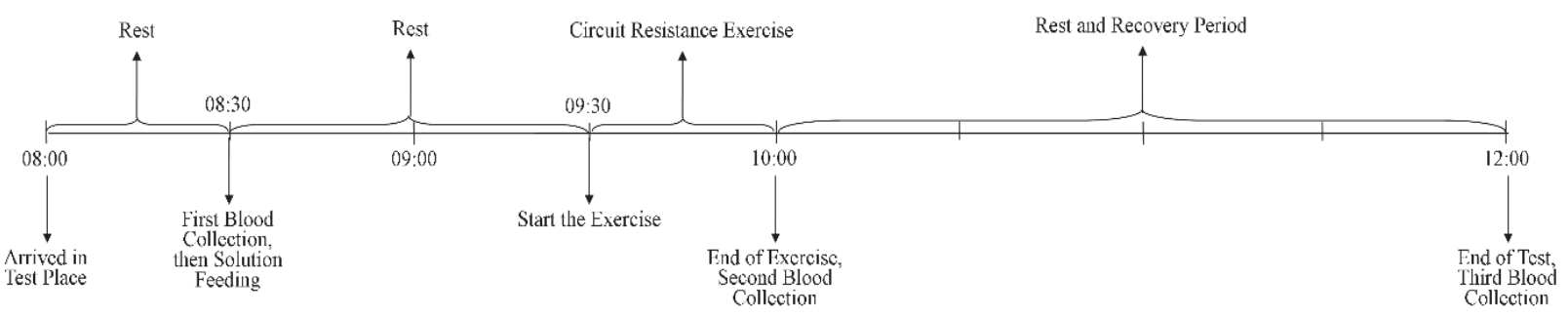

Fig. 1. Research Design and Blood Collection

Neutrophil's proteins and [Ca2+]i assessments. Determination of caspase-3 (E20120710034, 0.05-10 ng/ml), calpain-1 (E20120710031, 13-800 IU/L), calpastatin (E20120710032, 16-1000 IU/L), Bax (E20120710035, 0.3-90 ng/ml), and XIAP (E20120710036, 0.05-20 ng/ml) was analyzed by ELISA (Glory Science Co., Ltd, China). $\left[\mathrm{Ca}^{2+}\right]_{\mathrm{i}}$ assessed by Atomic Absorption/ Flame Emission method and SPECTROPHOTOMETER system (Shimadzu, AA-670).

Statistical analysis. Repeated measure (two-way) ANOVA was used to determine the effects of TIME and Group by SPSS software at significance level of $\mathrm{p}<0.05$.

\section{RESULTS}

Muchly's sphericity assumption was meet for $\left[\mathrm{Ca}^{2+}\right]_{\mathrm{i}}(\mathrm{W}=0.794 ; \mathrm{p}=0.281)$, calpastatin $(\mathrm{W}=0.904 ; \mathrm{p}=0.573)$, calpain-1 $(\mathrm{W}=0.849 ; \mathrm{p}=0.406)$, Bax $(\mathrm{W}=0.712 ; \mathrm{p}=0.154)$, XIAP $(\mathrm{W}=0.712 ; \mathrm{p}=0.154)$, and caspase-3 $(\mathrm{W}=0.884 ; \mathrm{p}=0.508)$.

$\left[\mathrm{Ca}^{2+}\right]_{i \cdot}$ The interaction effect of TIME $\times$ GROUP was significant $\left(\mathrm{F}_{2,24}=6.875 ; \mathrm{p}=0.005\right.$; $\eta^{2}=0.361$ ). Accordingly, it increased linearly in placebo group during Ex and recovery period (Pre.Ex = $=0.88 \pm 0.06$, Po.Ex $=1.28 \pm 0.02,2 \mathrm{hEx}=1.40 \pm 0.04 \mathrm{mg} / \mathrm{L})$. In contrast, in $\mathrm{Zj}$ group $\left[\mathrm{Ca}^{2+}\right]_{\mathrm{i}}$. levels remained unchanged over time $($ Pre.Ex $=1.47 \pm 0.01$, Po.Ex $=1.53 \pm 0.01,2 \mathrm{hEx}=1.68 \pm 0.08 \mathrm{mg} / \mathrm{L})$ (Fig. 2a).

Calpastatin. The interaction effect of TIME $\times$ GROUP was significant $\left(\mathrm{F}_{2,24}=4.802 ; \mathrm{p}=0.018\right.$; $\eta^{2}=0.286$ ). Accordingly, it decreased linearly during exercise and recovery in placebo group (Pre.Ex $=$ $=28 \pm 0.8, \mathrm{Po} . \mathrm{Ex}=26 \pm 0.6,2 \mathrm{hEx}=23 \pm 0.8 \mathrm{IU} / \mathrm{L})$. But in $\mathrm{Zj}$ group, it is increased and decreased during exercise and recovery periods (Pre.Ex $=26 \pm 1.2$, Po.Ex $=30 \pm 0.5,2 \mathrm{hEx}=25 \pm 0.7 \mathrm{IU} / \mathrm{L}$ ), respectively (Fig. 2b).

Calpain-1. The interaction effect of TIME $\times$ GROUP was significant $\left(F_{2,24}=14.799 ; \mathrm{p}<0.001\right.$; $\eta^{2}=0.552$ ). Although it remained unchanged immediately after exercise in both placebo (Pre.Ex $=257 \pm$ \pm 7.3 , Po.Ex $=256 \pm 5.7 \mathrm{IU} / \mathrm{L})$ and $\mathrm{Zj}(\operatorname{Pre} . \mathrm{Ex}=280 \pm 7.5$, Po.Ex $=276 \pm 6.7 \mathrm{IU} / \mathrm{L})$ group, a significant elevation and placebo $(2 \mathrm{hEx}=276 \pm 6.2 \mathrm{IU} / \mathrm{L})$ and decline in $\mathrm{Zj}(2 \mathrm{hEx}=259 \pm 5.2 \mathrm{IU} / \mathrm{L})$ group was found at 120 after exercise (Fig. 2c).

Bax. The interaction effect of TIMExGROUP was insignificant $\left(\mathrm{F}_{2,24}=1.154 ; \mathrm{p}=0.332\right.$; $\eta^{2}=0.088$ ) (Fig. 2d). Accordingly, it remained unchanged in both placebo (Pre.Ex $=37.5 \pm 5.4$, Po.Ex $=$ $=29.3 \pm 0.9,2 \mathrm{hEx}=30.1 \pm 1.0 \mathrm{ng} / \mathrm{ml})$ and $\mathrm{Zj}($ Pre.Ex $=30.1 \pm 0.8$, Po.Ex $=29.3 \pm 0.5,2 \mathrm{hEx}=29.8 \pm$ $\pm 3.1 \mathrm{ng} / \mathrm{ml}$ ) groups over time (Fig. $2 \mathrm{~d}$ ).

XIAP. The interaction effect of TIME $\times$ GROUP was significant $\left(\mathrm{F}_{2,24}=6.727 ; \mathrm{p}=0.005\right.$; $\eta^{2}=0.359$ ). Accordingly, it unchanged in both placebo (Pre.Ex $=4.21 \pm 0.26$, Po.Ex $=4.33 \pm$ $\pm 0.17 \mathrm{ng} / \mathrm{ml})$ and $\mathrm{Zj}($ Pre.Ex $=4.21 \pm 0.14$, Po.Ex $=4.47 \pm 0.12 \mathrm{ng} / \mathrm{ml})$ group during exercise, but during recovery it had reduction in placebo group $(2 \mathrm{hEx}=3.89 \pm 0.22 \mathrm{ng} / \mathrm{ml})$ and elevation in $\mathrm{Zj}$ group $(2 \mathrm{hEx}=4.83 \pm 0.18 \mathrm{ng} / \mathrm{ml})$ (Fig. 2e).

Caspase-3. The interaction effect of TIME $\times$ GROUP was significant $\left(\mathrm{F}_{2,24}=24.231 ; \mathrm{p}<0.001\right.$; $\left.\eta^{2}=0.669\right)$. Accordingly, levels increased linearly during both exercise and recovery in placebo group (Pre.Ex $=5.5 \pm 0.1$, Po.Ex $=6.0 \pm 0.1,2 \mathrm{hEx}=6.9 \pm 0.2 \mathrm{ng} / \mathrm{ml}$ ); and in $\mathrm{Zj}$ group, it unchanged during exercise and decreased during $120 \mathrm{~m}$ recovery period (Pre.Ex $=6.3 \pm 0.1$, Po.Ex $=6.0 \pm 0.2,2 \mathrm{hEx}=$ $=5.4 \pm 0.1 \mathrm{ng} / \mathrm{ml})($ Fig. 2f). 


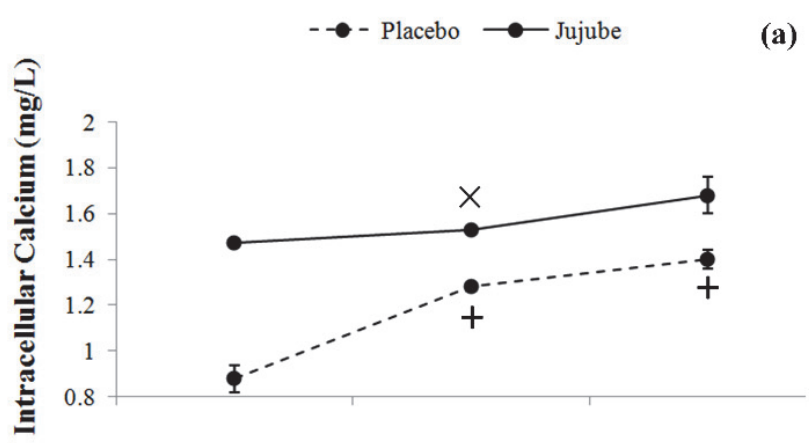

a)

(d)

(b)

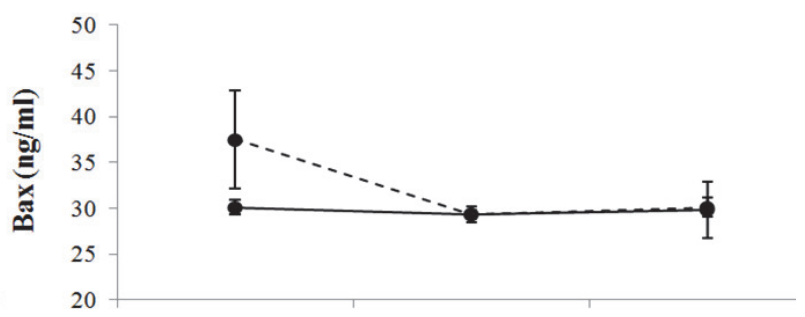

(e)
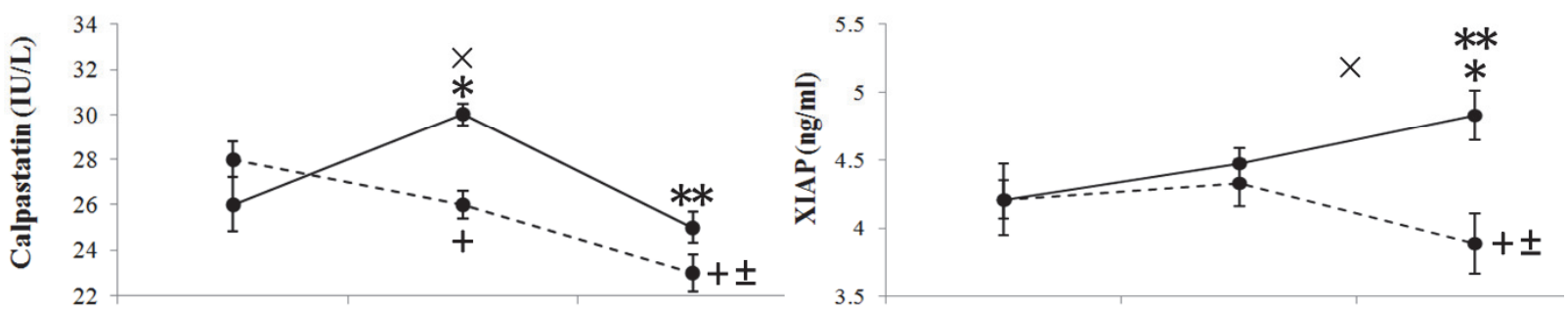

(c)
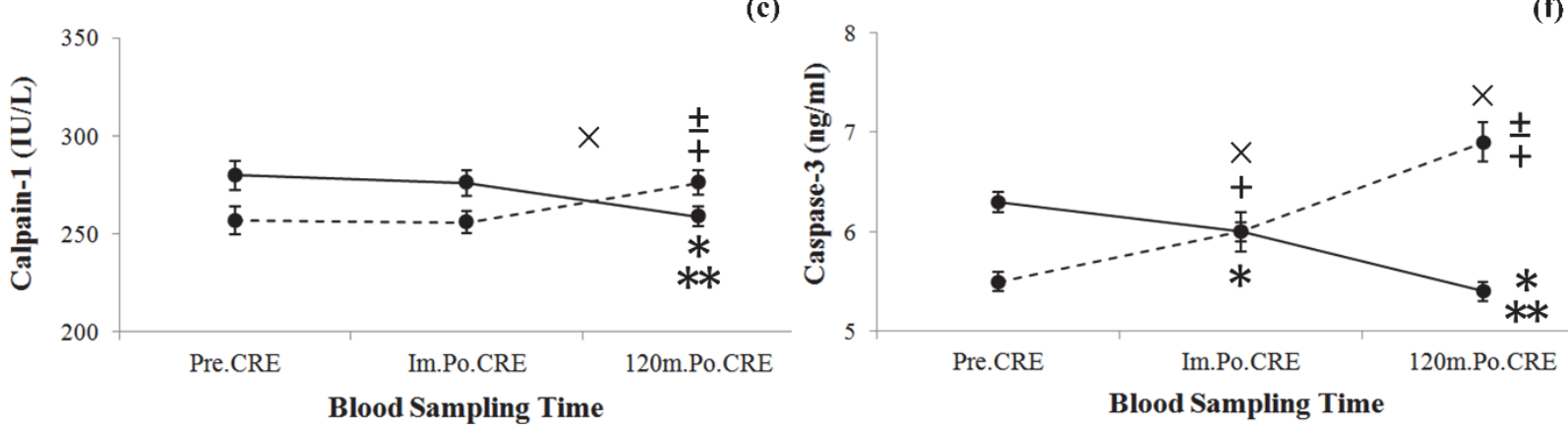

Fig. 2. The Acute Effect of Ziziphus jujuba Supplementation on some Pro- and Anti-Apoptotic Protein Levels of Human Neutrophils in Response to a Session of Intensive Circuit Resistance Exercise: a - effect on intracellular calcium levels; $b$ - effect on calpastatin expression; $c$ - effect on Calpain-1 expression; $d$ - effect on Bax expression; e effects on XIAP levels; $f$ - effects on Caspase-3 levels. Pre: previous. CRE: circuit resistance exercise. Im.po: Immediately Post. $120 \mathrm{~m}$ : 120 minutes. $\times$ - interaction effect of GROUP $\times$ TIME is significant at $p<0.05 ;+-$ significant diference with Pre.CRE in Placebo at $p<0.05 ; \pm-$ significant diference with Im.Po.CRE in Placebo at $p<0.05 ;{ }^{*}-$ significant diference with Pre.CRE in Jujube at $p<0.05 ;{ }^{* *}-$ significant diference with Im.Po.CRE in Jujube at $p<0.05$. Error Bars peresent as SE

\section{DISCUSSION}

Current data implicate that acute resistance exercise induced an increase of $\left[\mathrm{Ca}^{2+}\right]_{\mathrm{i}}$, calpain-1, and caspase-3, while XIAP and calpastatin levels decreased. Accordingly, pro-apoptotic molecular signals with involvement of $\left[\mathrm{Ca}^{2+}\right]_{\mathrm{i}}$-calpastatincalpain-caspase-3 axis were up-regulated in response to exercise. In contrast, supplementation with $\mathrm{Zj}$ attenuated the exercise induced increase of pro-apoptotic signals and increased the levels of anti-apoptotic signals such as XIAP.

In neutrophils the critical balance between cell life and cell death is regulated by the balance between levels of anti-apoptotic andpro-apoptotic proteins levels [14]. Although the neutrophils $\left[\mathrm{Ca}^{2+}\right]_{i}$-calpastatin-calpain axis was not investi- gated during exercise conditions before, it is supposed that the calcium-dependent cysteine proteasis calpain is an important mediator of neutrophil apoptosis. During the apoptosis process, calpastatin is broken down and calpains cleave the Bax, and deactivate XIAP, thus causing neutrophil apoptosis [9].

In placebo group, $\left[\mathrm{Ca}^{2+}\right]_{\mathrm{i}}$ levels increased during exercise and recovery. In parallel, antiapoptotic calpastatin decreased. While calpain-1 and XIAP remained unchanged during exercise, they increased or decreased during recovery, respectively. Caspase- 3 increased linearly during exercise and recovery suggesting that intensive Ex affects the balance between pro- and antiapoptotic proteins in neutrophils to pro-apoptosis. 


\section{Физиология}

An increase of neutrophil apoptosis after intensive exercise was found previously after acute exercise; Here, it a change in the oxidative state in neutrophils was documented which resulted in apoptosis [31]. Similarly, our own group found an increase of Annexin-positive neutrophils after intensive resistance exercise [35]. The involvement of $\left(\left[\mathrm{Ca}^{2+}\right]_{\mathrm{i}}\right)$ in apoptosis regulation during exercise was previously demonstrated in lymphocytes [22] and neutrophils [23]. Here it was found that exercise affect neutrophils calcium transients followed by a modulation of neutrophils life span. A study showed that incubation with Granulocyte Colony-Stimulating Factor (G-CSF) delayed in vitro neutrophils apoptosis for $12 \mathrm{~h}$ and prevented the activation of caspase- 3 and -9 . Besides it strongly prevented activation of calpains (upstream of caspase-3) through control of calcium permeation. Accordingly, it is strongly suggested that $\left[\mathrm{Ca}^{2+}\right]_{\mathrm{i}}$ modulation is involved in apoptosis during exercise with the involvement of calpains. In addition, prevention of Calpain caused stability of XIAP and so activity inhibition of caspase-3 and -9 [38].

The importance of the $\left[\mathrm{Ca}^{2+}\right]_{\mathrm{i}}$-calpastatincalpain axis for induction of apoptosis is supported by the contrary effects of $\mathrm{Zj}$ supplementation on neutrophils protein expression after exercise. Accordingly, in $\mathrm{Zj}$ solution group, increase of $\left[\mathrm{Ca}^{2+}\right]_{\mathrm{i}}$ was inhibited compared to placebo group. In accordance, calpastatin and XIAP increased while a decrease of calpain-1 was found the resulting decrease of caspase- 3 in $\mathrm{Zj}$ group suggested that supplementation one hour before exercise is able to reverse the exercise induced changes of pro- and anti- apoptotic proteins in human neutrophil. Similarly, glutamine feeding resulted in reduction neutrophils apoptosis induced by exercise; in which assumed that supplementation might have protective effects on mitochondrial integrity [18]. In other study, one session of exercise increased neutrophils' caspase-3 gene expression in rats, which was attenuated by supplementation with glutamine [16]. $\mathrm{Zj}$ fruit contains high carbohydrates, fat, protein, various amino acids such as three precursor of glutamine and several others [10]. Accordingly, it is suggested that glucose and glutamine are important energy sources of neutrophils during exercise [17], which might be more important than glucose [6]. Thus, $\mathrm{Zj}$ supplementation ( $0.5 \mathrm{gr} / \mathrm{kg}$ body weight in $2.5^{\mathrm{cc}}$ distilled water) might be an important provider of energy for neutrophils which is specifically important during energy demanding activities like circuit training. In accordance with our data, 30 days of $\mathrm{Zj}$ extraction supplementation reduced Bax expression and increased Bcl-2 expression in rats' heart muscle in response to two swimming bouts (15-min) on two days [21].

Besides, $\mathrm{Zj}$ contains various minerals and vitamins which have anti-oxidative we properties such as vitamins $\mathrm{C}$, and $\mathrm{A}$. It also contains glycoside complexes, including phenols (Querectin and Kaemferol) as well as flavonoids and triterpenes $[4,5,8]$, which also have anti-oxidative properties. We know that acute exercise with high intensity elevates oxidative stress and tissue damage [31], and intensive resistance training also have a profound effect on in lipid peroxidation and production of free radicals through blood ischemia-reperfusion and mechanical loads exerted on the involved soft tissues [1]. The involvement of oxidative mechanisms is likely because it was shown that exercise induced neutrophil apoptosis is related to an altered oxidative status $[31,35]$. In contrast, 3 weeks $\mathrm{Zj}$ administration $(0.4 \mathrm{gr} / \mathrm{kg}$ body weight) improved negative effect of a bout of resistance exercise (5 exercise with $90 \% 1 \mathrm{RM}$ ) on suppression of total antioxidant capacity [2] and glutathione peroxidase (GPX) [1]. It is found 30 days supplementation with $\mathrm{Zj}$ extraction reduced Bax expression and increased Bcl-2 expression in rats' heart muscle accompanied by reduced levels of lipid peroxidation and increase antioxidant enzymes activities [21].

\section{CONCLUSION}

In summary, intensive Ex turned protein balance in neutrophils to pro-apoptotic signals. In contrast supplementation with $\mathrm{Zj}$ solution an hour before exercise suppressed these responses suggesting that supplementation inhibits cell death. Mechanistically, it is suggested that the $\left[\mathrm{Ca}^{2+}\right]_{\mathrm{i}}$-Calpastatin-Calpain axis upstream caspase-3 is involved in exercise induced apoptosis modulation of neutrophils. The modifying effects of $\mathrm{Zj}$ on this pathway might be due the supply of energy or its anti-oxidative capacity. Any clinical effects of $\mathrm{Zj}$ on the immune system after exercise remain to be shown in future studies.

\section{References}

1. Afzalpour M.E., Abtahi Eivari H., Rezazadeh A., Soluki A. Effect of Ziziphus jujuba Supplementation before One Session of Acute Resistance Exercise on the Serum Glutathione Peroxidase and Superoxide Dismutase Activity. 
$Q$ Horiz Med Sci, 2015, vol. 21 (2), pp. 97-104. DOI: 10.18869/acadpub.hms.21.2.97

2. Afzalpour M.E., Rezazadeh A., Abtahi S.H. Effects of Jujube Fruit on Total Antioxidant Capacity and Lipid Peroxidation in Young Women After an Intensive Resistance Exercise Session. Sport Biomot Sci, 2014, vol.6(11), pp. 16-26.

3. Altznauer F., Conus S., Cavalli A. et al. Calpain-1 Regulates Bax and Subsequent SmacDependent Caspase-3 Activation in Neutrophil Apoptosis. J Biol Chem, 2004, vol. 279 (7), pp. 5947-5957. DOI: $10.1074 /$ jbc.M308576200

4. Cheng D., Zhu C., Cao J., Jiang W. The Protective Effects of Polyphenols from Jujube Peel (Ziziphus Jujube Mill) on Isoproterenol-Induced Myocardial Ischemia and Aluminum-Induced Oxidative Damage in Rats. Food Chem Toxicol, 2012, vol. 50 (5), pp. 1302-1308. DOI: $10.1016 /$ j.fct.2012.01.026

5. Choi S.H., Ahn J.B., Kozukue N. et al. Distribution of Free Amino Acids, Flavonoids, Total Phenolics, and Antioxidative Activities of Jujube (Ziziphus Jujuba) Fruits and Seeds Harvested from Plants Grown in Korea. J Agric Food Chem, 2011, vol. 59 (12), pp. 6594-6604. DOI: $10.1021 /$ jf200371r

6. Curi T.C., De Melo M.P., De Azevedo R.B. et al. Glutamine Utilization by Rat Neutrophils: Presence of Phosphate-Dependent Glutaminase. Am J Physiol, 1997, vol. 273 (4 Pt 1), pp. 1124-1129. DOI: 10.1152/ajpcell.1997.273. 4.C1124

7. Cury-Boaventura M.F., Levada-Pires A.C., Folador A. et al. Effects of Exercise on Leukocyte Death: Prevention by Hydrolyzed whey Protein Enriched with Glutamine Dipeptide. Eur J Appl Physiol, 2008, vol. 103 (3), pp. 289-294. DOI: 10.1007/s00421-008-0702-1

8. Gao Q.-H., Wu P.-T., Liu J.-R. et al. Physico-Chemical Properties and Antioxidant Capacity of Different Jujube (Ziziphus jujuba Mill.) Cultivars Grown in Loess Plateau of China. Sci Hortic, 2011, vol. 130 (1), pp. 67-72. DOI: $10.1016 /$ j.scienta.2011.06.005

9. Geering B., Simon H.U. Peculiarities of Cell Death Mechanisms in Neutrophils. Cell Death Differ, 2011, vol. 18 (9), pp. 1457-1469. DOI: $10.1038 /$ cdd.2011.75

10. Ghanbari Niaki A., Mohammadi Joojadeh F., Zare Kookandeh N. et al. Liver and Plasma Nesfatin-1 Responses to 6 Weeks of Treadmill Running with or without Zizyphus Jujuba Liquid Extract in Female Rat. Int $J$
Endocrinol Metab, 2013, vol. 11 (2), pp. 95-101. DOI: $10.5812 /$ ijem. 8438

11. Guo S., Duan J.-A., Tang Y. et al. HighPerformance Liquid Chromatography - Two Wavelength Detection of Triterpenoid Acids from the Fruits of Ziziphus Jujuba Containing Various Cultivars in Different Regions and Classification Using Chemometric Analysis. J Pharm Biomed Anal, 2009, vol. 49 (5), pp. 1296-1302. DOI: $10.1016 /$ j.jpba.2009.03.006

12. Hamedi S., Arian A.A., Farzaei M.H. Gastroprotective Effect of Aqueous Stem Bark Extract of Ziziphus Jujuba L. Against HCl/EthanolInduced Gastric Mucosal Injury in Rats. $J$ Tradit Chin Med, 2015, vol. 35 (6), pp. 666-670. DOI: 10.1016/S0254-6272(15)30157-6

13. Huang Y.L., Yen G.C., Sheu F., Chau C.F. Effects of Water-Soluble Carbohydrate Concentrate from Chinese Jujube on Different Intestinal and Fecal Indices. J Agric Food Chem, 2008, vol. 56 (5), pp. 1734-1739. DOI: 10.1021/ jf072664z

14. Kroemer G., Dallaporta B., RescheRigon M. The Mitochondrial Death/Life Regulator in Apoptosis and Necrosis. Annu Rev Physiol, 1998, vol. 60, pp. 619-642. DOI: 10.1146/ annurev.physiol.60.1.619

15. Lagranha C.J., deLima T.M., Senna S.M. et al. The Effect of Glutamine Supplementation on the Function of Neutrophils From Exercised Rats. Cell Biochem Funct, 2005, vol. 23 (2), pp. 101-107. DOI: 10.1002/cbf.1192

16. Lagranha C.J., Hirabara S.M., Curi R., Pithon-Curi T.C. Glutamine Supplementation Prevents Exercise-Induced Neutrophil Apoptosis and Reduces p38 MAPK and JNK Phosphorylation and p53 and Caspase 3 Expression. Cell Biochem Funct, 2007, vol. 25 (5), pp. 563-569. DOI: $10.1002 /$ cbf. 1421

17. Lagranha C.J., Levada-Pires A.C., Sellitti D.F. et al. The Effect of Glutamine Supplementation and Physical Exercise on Neutrophil Function. Amino Acids, 2008, vol. 34 (3), pp. 337-346. DOI: 10.1007/s00726-007-0560-x

18. Lagranha C.J., Senna S.M., De Lima T.M. et al. Beneficial Effect of Glutamine on ExerciseInduced Apoptosis of Rat Neutrophils. Med Sci Sports Exerc, 2004, vol. 36 (2), pp. 210-217. DOI: 10.1249/01.MSS.0000113490.98089.B1

19. Li J.-W., Fan L.-P., Ding S.-D., Ding X.-L. Nutritional Composition of Five Cultivars of Chinese Jujube. Food Chemistry, 2007, vol. 103 (2), pp. 454-460. DOI: 10.1016/j. foodchem.2006.08.016 
20. Li J., Shan L., Liu Y., Fan L., Ai L. Screening of a Functional Polysaccharide from Zizyphus Jujuba cv. Jinsixiaozao and its Property. Int J Biol Macromol, 2011, vol. 49 (3), pp. 255-259. DOI: 10.1016/j.ijbiomac.2011. 04.006

21. Liang S., Juan J. Effect of Jujube Extract on Oxidative Injury in Heart Muscles of Exhausted Training Rats. Afr J Microbiol Res, 2011, vol. 5 (14), pp. 1896-1899. DOI: 10.5897/ AJMR11.447

22. Liu R., Fan W., Kruger K., et al. Exercise Affects T-Cell Function by Modifying Intracellular Calcium Homeostasis. Med Sci Sports Exerc, 2017, vol. 49 (1), pp. 29-39. DOI: $10.1249 / \mathrm{mss} .0000000000001080$

23. Mooren F.C., Völker K., Klocke R., et al. Exercise Delays Neutrophil Apoptosis by a G-CSF-Dependent Mechanism. $J$ Appl Physiol, 2012, vol. 113 (7), pp. 1082-1090. DOI: 10.1152/japplphysiol.00797.2012

24. Nieper A. Nutritional Supplement Practices in UK Junior National Track and Field Athletes. Br J Sports Med, 2005, vol. 39 (9), pp. 645-649. DOI: 10.1136/bjsm.2004.015842

25. Pawlowska A.M., Camangi F., Bader A., Braca A. Flavonoids of Zizyphus jujuba L. and Zizyphus spina-christi (L.) Willd (Rhamnaceae) fruits. Food Chem, 2009, vol. 112 (4), pp. 858-862. DOI: $10.1016 /$ j.foodchem.2008.06.053

26. Plastina P., Bonofiglio D., Vizza D. et al. Identification of Bioactive Constituents of Ziziphus Jujube Fruit Extracts Exerting Antiproliferative and Apoptotic Effects in Human Breast Cancer Cells. J Ethnopharmacol, 2012, vol. 140 (2), pp. 325-332. DOI: 10.1016/j.jep.2012.01.022

27. Rodríguez Villanueva J., Rodríguez Villanueva L. Experimental and Clinical Pharmacology of Ziziphus jujuba Mills. Phytotherapy Res, 2017, n/a-n/a. DOI: 10.1002/ptr.5759

28. Sabzghabaee A.M., Khayam I., Kelishadi R. et al. Effect of Zizyphus Jujuba Fruits on Dyslipidemia in Obese Adolescents: a TripleMasked Randomized Controlled Clinical Trial. Med Arch, 2013, vol. 67 (3), pp. 156-159. DOI: 10.5455/medarh.2013.67.156-160

29. Shen X., Tang Y., Yang R. et al. The Protective Effect of Zizyphus Jujube Fruit on Carbon Tetrachloride-Induced Hepatic Injury in Mice by Anti-Oxidative Activities. $J$ Ethnopharmacol, 2009, vol. 122 (3), pp. 555-560. DOI: 10.1016/j.jep.2009.01.027

30. Striegel H., Simon P., Wurster C. et al.
The Use of Nutritional Supplements Among Master Athletes. Int J Sports Med, 2006, vol. 27 (3), pp. 236-241. DOI: $10.1055 / \mathrm{s}-2005-865648$

31. Syu G.D., Chen H.I., Jen C.J. Severe Exercise and Exercise Training Exert Opposite Effects on Human Neutrophil Apoptosis via Altering the Redox Status. PLoS One, 2011, vol. 6 (9), e24385. DOI: 10.1371/journal.pone.0024385

32. Taati M., Alirezaei M., Meshkatalsadat M.H. et al. Antioxidant Effects of Aqueous Fruit Extract of Ziziphus Jujuba on Ethanol-Induced Oxidative Stress in the Rat Testes. Iran J Vet Res, 2011, vol. 12 (1), pp. 39-45.

33. Tayebi S.M., Saeidi A., Gharahcholo L. et al. Acute and Short-Term Effects of Oral Jujube Solution on White Blood Cell and its Differential count in Response to Circuit Resistance Exercise. International Journal of Applied Exercise Physiology, 2016, vol. 5 (2), pp. 1-10.

34. Tayebi S.M., Agha-Alinejad H., Shafaee S. et al. Acute Effects of Jujube Ziziphus Solution Feeding before a Single Session of Circuit Resistance Exercise on Apoptosis of Human Neutrophil. Journal of Applied Exercise Physiology, 2017, vol. 13 (25), pp. 97-114. DOI: 10.22080/jaep.2017.1591

35. Tayebi S.M., Agha-Alinejad H., Shafaee S. et al. Short-Term Effects of Oral Feeding Jujube Ziziphus Solution before a Single Session of Circuit Resistance Exercise on Apoptosis of Human Neutrophil. Ann Appl Sport Sci, 2014, vol. 2 (1), pp. 53-68. DOI: 10.18869/acadpub.aassjournal.2.1.53

36. Tayebi S.M., Saeidi A., Mahmoudi A.A. et al. Acute and Short-Term Effects of Oral Feeding of Jujube Solution on Blood Platelets and its Morphological Indices in Response to a Circuit Resistance Exercise. Annals of Applied Sport Science, 2015, vol. 3 (3), pp. 67-82. DOI: 10.18869/acadpub.aassjournal.3.3.67

37. Vahedi F., Fathi Najafi M., Bozari K. Evaluation of Inhibitory Effect and Apoptosis Induction of Zyzyphus Jujube on Tumor Cell Lines, an in Vitro Preliminary Study. Cytotechnol, 2008, vol. 56 (2), pp. 105-111. DOI: 10.1007/s10616-008-9131-6

38. van Raam B.J., Drewniak A., Groenewold V. et al. Granulocyte Colony-Stimulating Factor Delays Neutrophil Apoptosis by Inhibition of Calpains Upstream of Caspase-3. Blood, 2008, vol. 112 (5), pp. 2046-2054. DOI: 10.1182/blood-2008-04-149575

39. Xue Z., Feng W., Cao J. et al. Antioxi- 
dant Activity and Total Phenolic Contents in Peel and Pulp of Chinese Jujube (Ziziphus Jujuba Mill) Fruits. J Food Biochem, 2009, vol. 33 (5), pp. 613-629. DOI: $10.1111 / \mathrm{j} .1745-4514.2009$. 00241.X

40. Yoo K.Y., Li H., Hwang I.K. et al. Zizyphus Attenuates Ischemic Damage in the Gerbil Hippocampus via its Antioxidant Effect. $J$ Med
Food, 2010, vol. 13 (3), pp. 557-563. DOI: 10.1089/jmf.2009.1254

41. Yu L., Jiang B.P., Luo D. et al. Bioactive Components in the Fruits of Ziziphus Jujuba Mill. Against the Inflammatory Irritant Action of Euphorbia Plants. Phytomed, 2012, vol. 19 (3-4), pp. 239-244. DOI: 10.1016/j. phymed.2011.09.071

Received 20 June 2020

\title{
ВЛИЯНИЕ УПОТРЕБЛЕНИЯ ЗИЗИФУСА НАСТОЯЩЕГО НА ПРО- И АНТИАПОПТОТИЧЕСКУЮ ЭКСПРЕССИЮ БЕЛКА В НЕЙТРОФИЛАХ ПОСЛЕ СИЛОВЫХ УПРАЖНЕНИЙ
}

\author{
С.м. Тайеби ${ }^{1}$, К. Крюгер ${ }^{2}$, м. Сафакар ${ }^{3}$, п. Бахрами ${ }^{3}$, \\ Г. Тахмасб $\sigma^{3}$, А.В. Ненашева ${ }^{4}$ \\ ${ }^{1}$ Университет им. Алламе Табатабаи, г. Тегеран, Иран, \\ ${ }^{2} Г$ Гисенский Университет им. Юстуса Либиха, г. Гиссен, Германия, \\ ${ }^{3}$ Исламский Университет Азад в г. Керман, г. Керман, Иран, \\ ${ }^{4}$ Южно-Уральский государственный университет, г. Челябинск, Россия
}

\begin{abstract}
Считается, что зизифус способен оказывать положительное воздействие на иммунные расстройства, вызванные физической нагрузкой, в частности, речь идет о регуляции апоптоза нейтрофилов, однако ее внутриклеточный механизм все еще остается неизученным. Цель. Цель данного исследования - изучить мгновенный эффект от употребления зизифуса настоящего на про- и антиапоптотический уровни белка в нейтрофилах человека в ответ на сеанс круговой тренировки. Материалы и методы. Участники завершили круговую тренировку (75 \%, 1ПМ, 9 упражнений, 3 подхода). Пока одна группа получала плацебо, другая группа ежедневно употребляла зизифус $\left(0,5\right.$ г/кг веса тела в $2,5 \mathrm{~cm}^{3}$ дистиллированной воды) за час до тренировки. Результаты. У участников группы, получавшей плацебо, повысился уровень нейтрофилов $\left[\mathrm{Ca}^{2+}\right]_{\text {i }}$, кальпаина-1 и каспазы-3 $(\mathrm{p}<0,05)$ при одновременном снижении уровня кальпастатина и Х-связанного ингибитора белка апоптоза $(\mathrm{p}<0,05)$. В свою очередь зизифус либо подавлял $\left[\mathrm{Ca}^{2+}\right]_{i}$, либо реверсировал ответы на кальпастатин, кальпаин-1, Х-связанный ингибитор белка апоптоза и каспазу-3 (p < 0,01). Заключение. Данные показывают, что один сеанс интенсивной круговой тренировки индуцировал апоптотическую передачу сигналов в нейтрофилах человека с участием оси $\left[\mathrm{Ca}^{2+}\right]_{\mathrm{i}}$-кальпастатин-кальпаин, расположенной выше каспазы-3. Однократный прием раствора зизифуса перед тренировкой ослабил эти эффекты, вероятно, за счет обеспечения источников энергии для нейтрофилов или за счет функционирования в качестве антиоксидантов.
\end{abstract}

Ключевые слова: добавка зизифуса, силовые упражнения, апоптоз нейтрофилов, ось $\left[\mathrm{Ca}^{2+}\right]_{i}$-кальпастатин-кальпаин, каспаза-3, Х-связанный ингибитор белка апоптоза. 
Тайеби Сейед Мортеза, кафедра физиологии упражнений, факультет спортивных наук, Университет им. Алламе Табатабаи, г. Тегеран, Иран. E-mail: tayebism@atu.ac.ir, tayebism@ gmail.com, ORCID: 0000-0003-0459-4443.

Крюгер Карстен, кафедра физиологии упражнений и спортивной терапии, Гисенский Университет им. Юстуса Либиха, г. Гиссен, Германия. E-mail: karsten.krueger@sport.uni-giessen.de, ORCID: 0000-0003-1506-8254.

Сафакар Мехрнуш, кафедра физиологии упражнений, гуманитарный факультет, Исламский университет Азад в г. Керман, г. Керман, Иран. E-mail: safakar.m@yahoo.com. ORCID: 0000-0002-6355-2107.

Бахрами Поуран, кафедра физиологии упражнений, гуманитарный факультет, Исламский университет Азад в г. Керман, г. Керман, Иран. E-mail: bahrami.pouran@yahoo.com. ORCID: 0000-0002-0111-2077.

Тахмасб Гасем, кафедра физиологии упражнений, гуманитарный факультет, Исламский университет Азад в г. Керман, г. Керман, Иран. E-mail: tahmasb.g@yahoo.com. ORCID: 0000-0002-6663-4319.

Ненашева Анна Валерьевна, кафедра теории и методики физической культуры и спорта, кафедра спортивного совершенствования, Институт спорта, туризма и сервиса, Южно-Уральский государственный университет (национальный исследовательский университет). 454080, г. Челябинск, проспект Ленина, 76. E-mail: nenashevaav@susu.ru, ORCID: 0000-0003-0092-2948.

Поступила в редакцию 20 июня 2020 2.

\section{ОБРАЗЕЦ ЦИТИРОВАНИЯ}

Effects of Ziziphus Jujube Supplementation on Proand Anti-Apoptotic Protein Expression in Neutrophils after Resistance Exercise / S.M. Tayebi, K. Krüger, M. Safakar et al. // Человек. Спорт. Медицина. - 2020. - Т. 20, № 3. - C. 5-14. DOI: 10.14529/hsm200301

\section{FOR CITATION}

Tayebi S.M., Krüger K., Safakar M., Bahrami P., Tahmasb G., Nenasheva A.V. Effects of Ziziphus Jujube Supplementation on Pro- and Anti-Apoptotic Protein Expression in Neutrophils after Resistance Exercise. Human. Sport. Medicine, 2020, vol. 20, no. 3, pp. 5-14. DOI: $10.14529 / \mathrm{hsm} 200301$ 